
(C) 2019 by the Arizona Board of Regents on behalf of the University of Arizona. This is an Open Access article, distributed under the terms of the Creative Commons Attribution-NonCommercial-ShareAlike licence (https://creativecommons.org/licenses/by-nc-sa/4.0/), which permits non-commercial re-use, distribution, and reproduction in any medium, provided the same Creative Commons licence is included and the original work is properly cited. The written permission of Cambridge University Press must be obtained for commercial re-use.

\title{
RADIOCARBON AGE OFFSETS OF PLANTS AND BIOCLASTS IN THE HOLOCENE SEDIMENTS FROM THE MIYAZAKI PLAIN, SOUTHEAST COAST OF KYUSHU, SOUTHWEST JAPAN
}

Toshimichi Nakanishi ${ }^{1,2}$ - Wan Hong ${ }^{3 *}$ (D) Mitsuhiro Kuwahata ${ }^{4}$ • Shinji Sugiyama ${ }^{5}$ Shoichi Shimoyama ${ }^{6} \cdot$ Ken'ichi Ohkushi $^{7} \cdot$ Tatsuhiko Yamaguchi $^{8} \cdot$



${ }^{1}$ Institute for Geothermal Sciences, Graduate School of Science, Kyoto University, Noguchibaru, Beppu, Oita 874-0903, Japan

${ }^{2}$ Present address: Tono Geoscience Center, Japan Atomic Energy Agency, 959-31, Jorinji, Izumi-cho, Toki, Gifu 509-5102, Japan

${ }^{3}$ Geochemical Analysis Center, Korea Institute of Geoscience \& Mineral Resources, 124 Gwahak-ro, Yuseong-gu, Daejeon 34132, Republic of Korea

${ }^{4}$ Miyakonojyo City Board of Education, Ayamebaru-cho 19-1, Miyakonojo, Miyazaki 885-0034, Japan

${ }^{5}$ Paleoenvironment Research Center Co. Ltd., Akae 139-3, Miyazaki 880-0912, Japan

${ }^{6}$ Institute of Lowland and Marine Research, Saga University, Honjyo 1, Saga 840-8502, Japan

${ }^{7}$ Graduate School of Human Development and Environment, Kobe University, Tsurukabuto 3-11, Nada-ku, Kobe 657-8501, Japan

${ }^{8}$ National Museum of Nature and Science, 4-1-1 Amakubo, Tsukuba, Ibaraki 305-0005, Japan

${ }^{9}$ Geological Survey of Japan, Advanced Industrial Science \& Technology, Higashi 1-1-1, Tsukuba, Ibaraki 305-8567, Japan

${ }^{10}$ Implementation Research and Education System Center for Reducing Disaster Risk, Graduate School of Science and Technology, Kumamoto University, 2-39-1, Chuo-ku, Kurokami, Kumamoto 860-8555, Japan

\begin{abstract}
To investigate the relationship between paleoenvironmental changes and marine reservoir effects, the radiocarbon ages of marine bioclasts and terrestrial plants from the same horizons of a sediment core in the Holocene Epoch were measured. This core, with a length of approximately $9 \mathrm{~m}$, was obtained from the southern part of the Miyazaki Plain southeast of Kyushu Island, which faces the Kuroshio warm current. This drilling site is located in an uplift area associated with the subduction of the Philippine Sea Plate. Based on analyses of lithology, molluscan and foraminifera assemblages, and radiocarbon dating, we interpreted four sedimentary units in order of age: tidal flat, inner bay, Kikai-Akahoya volcanic ash, and delta plain. These paleoenvironmental changes were mainly associated with the sea-level rise during the deglacial period. The reservoir ages of nine pairs from the tidal flat to inner bay facies were found to be from the time span of $7300-8200 \mathrm{cal}$ BP. The chronological changes in the reservoir effect are correlated with those seen in Holocene sediments of the other coastal area in East Asia.
\end{abstract}

KEYWORDS: AMS radiocarbon dating, Holocene sediment, marine reservoir, Miyazaki Plain, sedimentary facies.

\section{INTRODUCTION}

The radiocarbon $\left({ }^{14} \mathrm{C}\right)$ marine reservoir effect, the age difference between the ocean ${ }^{14} \mathrm{C}$ and the contemporaneous atmosphere, is indispensable information for chronological control of geological and archaeological marine samples (e.g. Stuiver et al. 1986; Jull et al. 2013; Marine Reservoir Correction Database). This effect varies in time and location associated with changes in surface ocean circulation and geomorphologic environment. To address this problem, the relationship between the reservoir effect and paleoenvironmental change has been investigated using Holocene coastal sediments in the East Asia region

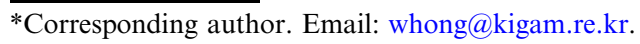


(Nakanishi et al. 2013, 2015, 2017a, 2017b, 2017c, 2019; Yang et al. 2018). The reservoir ages of these areas from $100 \mathrm{cal} \mathrm{BP}$ to $10,200 \mathrm{cal} \mathrm{BP}$ were found to range between 60 and 1100 years. To identify the chronological changes in the reservoir effect and paleoenvironment of the Miyazaki Plain southeast of Kyushu Island (Figure 1A), the ${ }^{14} \mathrm{C}$ ages of marine bioclasts and terrestrial plants from the same horizons of one core were measured. The results were then compared to values from the adjacent alluvial plains and inner bay (Nakanishi et al. 2017a, 2017c, 2019), the Korean Peninsula (Nakanishi et al. 2013, 2015, 2017b), the South China Sea (Yu et al. 2010), and Taiwan (Yang et al. 2018).

\section{STUDY SITE AND SAMPLE COLLECTION}

The Miyazaki Plain is located on the southeastern side of Kyushu Island in western Japan (Figure 1A). This region is located on an uplift area associated with the convergence of the Philippine Sea Plate, because marine terraces formed in the late Pleistocene and Holocene are well distributed (Figure 1B, Fitch and Scholz 1971; Nagaoka 1986; Nagaoka et al. 1991; Hasegawa et al. 2018). The coastal water around the plain is influenced by the warm Kuroshio Current, which originates from the southern area of the Northern Pacific Ocean. The Miyazaki alluvial plain was mainly formed by the Oyodo, Omaru, and Hitotsuse Rivers flowing from south to north. A melange matrix of accretionary complexes of the Early Cretaceous and Early Oligocene and volcanic rocks of the Early Pleistocene and Holocene form the bedrock of this catchment, in which no carbonate rocks are present (Kino et al. 1984). A sediment core (MIK: Miyazaki Ikime) with a length of approximately $9 \mathrm{~m}$ was obtained from the southern part of the plain $\left(31^{\circ} 56^{\prime} 42.2^{\prime \prime} \mathrm{N}, 131^{\circ} 22^{\prime} 280^{\prime \prime E}\right.$; elevation $\left.+14.08 \mathrm{~m}\right)$. Ancient tombs (Ikime Kofun gun) are distributed on marine terraces of the Late Miocene and Holocene, and non-alkaline pyroclastic flow deposit is distributed around the drilling site (Kino et al. 1984; Miyazaki City Board of Education 2010). The sample collection was started from a depth of $6.60 \mathrm{~m}$ because the drilling site occupied a thick embankment to construct a playground. MIK cores with a depth of $6.60-15.55 \mathrm{~m}$ were collected with $1.0-\mathrm{m}$ intervals using a doublewalled tube sampler. The total recovery was almost $96 \%$.

\section{METHODS}

\section{Sedimentological Analysis}

The MIK cores were split lengthwise into two halves and photographed. Their lithologies, colors, sedimentary structures, textures, contract characteristics, fossil components, and grain sizes were investigated. In addition, for a better understanding of the sedimentary environments, mollusk assemblages were identified based on the classification of Okutani (2000). To determine the physical properties of the sediments, sand contents and bulk densities were measured for 17 samples with lengths of 3 to $5 \mathrm{~cm}$. Using the separated sand particles, assemblages of foraminifera and ostracoda were also identified.

\section{AMS ${ }^{14} \mathrm{C}$ Dating}

Ten terrestrial macrofossils and ten carbonate marine samples in good condition were collected from the cores for accelerator mass spectrometry (AMS) ${ }^{14} \mathrm{C}$ dating. The sampling depths are listed in Table 1. Fragile samples such as leaves and thin bivalves as 
A $\quad \mathrm{E} 110^{\circ}$ $\mathrm{E} 130^{\circ}$

$\mathrm{E} 150^{\circ}$

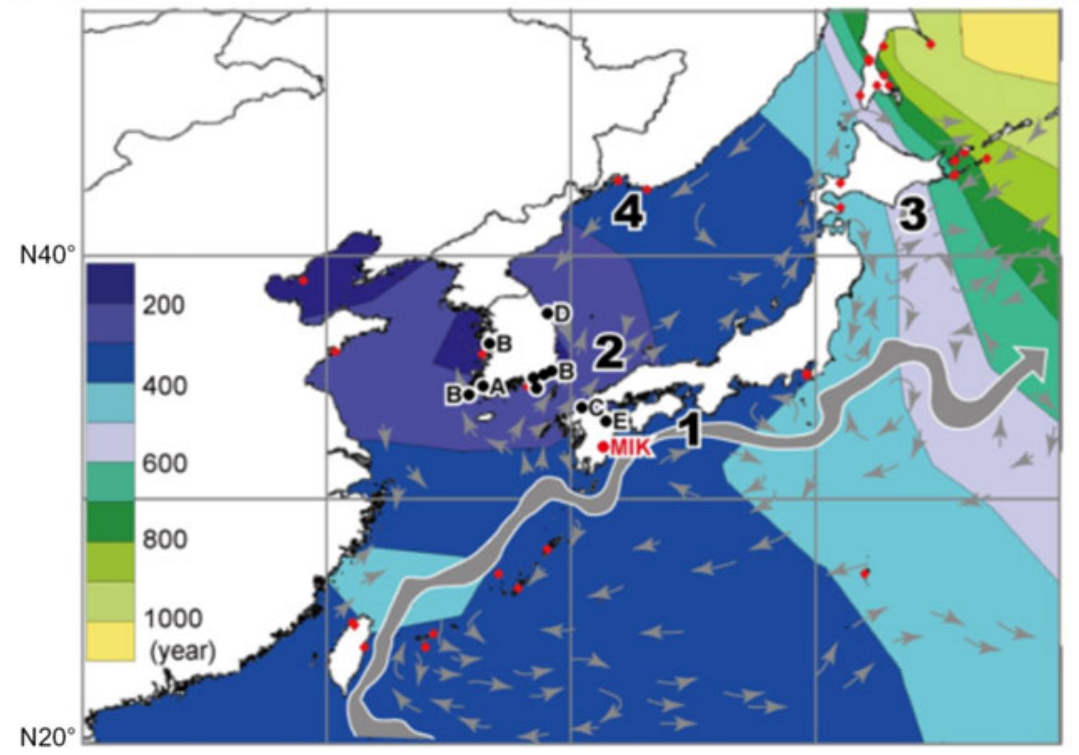

B

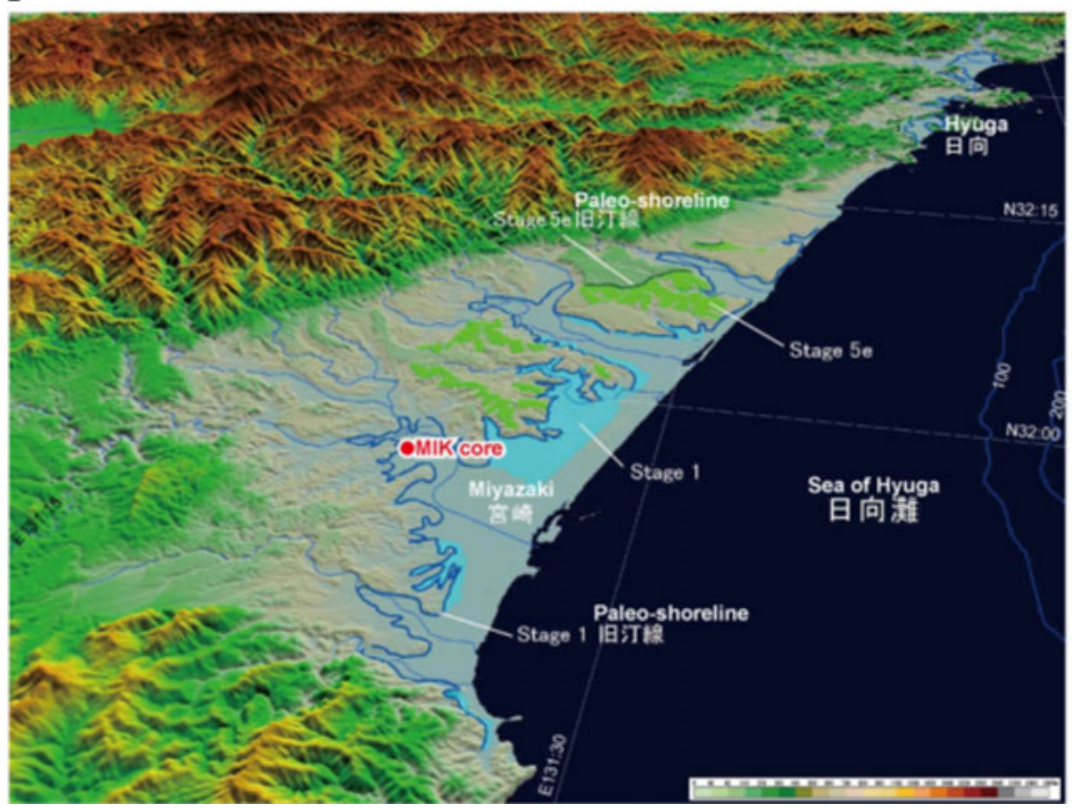

Figure 1 A. Study sites and modern marine reservoir ages (R) in East Asia (modified after Nakanishi et al. 2015). Data from Marine Reservoir Database. The contour lines were drawn using the Kriging method with the Surfer 8 code (Golden Software, Colorado, USA). 1-Kuroshio Current, 2-Tsushima Current, 3-Oyashio Current, 4-Liman Current. B. Drilling site of MIK (Miyazaki Ikime) core and geomorphologic interpretaion of the Miyazaki Plain (modified after Koike and Machida 2001). Marine terraces of Stage 5e and Stage 1 clearly indicate that drilling site is located on an uplifting area (Nagaoka 1986; Nagaoka et al. 1991; Hasegawa et al. 2018). 
Table 1 Radiocarbon ages from MIK core. Errors are 1 sigma ranges. Medium depths with an asterisk $(* 1-8)$ are those used to measure the marine reservoir age.








Figure 2 Sediment column, interpretation of paleoenvironments, sand content, bulk density, $\delta^{13} \mathrm{C}$ values of bioclasts measured on the AMS, and weights of ${ }^{14} \mathrm{C}$ dating samples of the MIK core.

well as articulated shells of dominant species were selected as far as possible because they are less likely to have been reworked. Samples were washed repeatedly in an ultrasonic cleaner and then organic samples were cleaned chemically using acid-alkali-acid or acid treatment to remove secondary contaminants. Samples of radiocarbon-free wood and the IAEA C-1 reference material were treated using the same procedure for blank-control measurements. The carbonate samples were powdered by mortar and pestle. All the samples including NIST OxII, IAEA C-7, and C-8 were combusted in an elemental analyzer, and the $\mathrm{CO}_{2}$ gas was purified cryogenically in a high-vacuum automatic preparation system (Hong et al. 2010a; Park et al. 2010) and then converted into graphite by reduction with Fe powder and hydrogen gas in a quartz tube. The ${ }^{14} \mathrm{C}$ ages of the samples were measured with the standard samples at the AMS facility at the Korea Institute of Geosciences and Mineral Resources (KIGAM) (Hong et al. 2010b). The isotopic fractionations were corrected by $\delta^{13} \mathrm{C}$ values, measured at the AMS facility. The ${ }^{14} \mathrm{C}$ ages of the terrestrial samples were converted into calendar dates using IntCal13 (Reimer et al. 2013) and CALIB 7.1 (Stuiver et al. 2018).

\section{RESULTS}

Based on our core analysis, four sedimentary facies were identified, namely tidal flat, inner bay, Kikai-Akahoya (K-Ah: Machida and Arai 2003) volcanic ash, and delta plain, as illustrated in Figure 2. These lithofacies along with remarks; depositional environments; assemblages of mollusk, ostracoda, and foraminifera; sand content; bulk density; $\delta^{13} \mathrm{C}$ values of bioclasts 


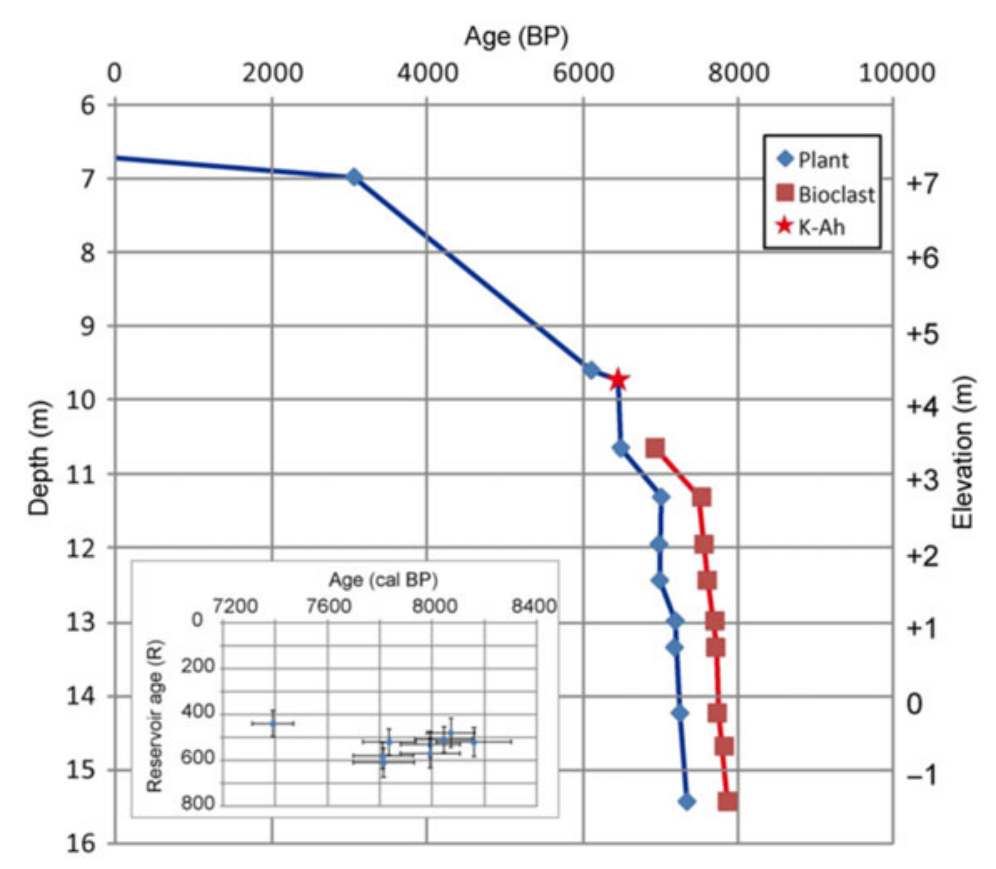

Figure 3 Accumulation curve and reservoir age of the MIK core.

measured on the AMS; and ${ }^{14} \mathrm{C}$ ages of the facies are described below. The ${ }^{14} \mathrm{C}$ ages are listed in Table 1, and an age/depth diagram is provided in Figure 3.

\section{Tidal Flat Facies (core depth of 12.85-15.55 m)}

\section{Description}

This sedimentary facies consisted of a sandy silt bed with a few sand layers, terrestrial plant fragments, crustaceans such as Brachyura and Pleocyemata, shells, bioturbation, and burrows. This sediment consisted of two units. The upper unit consisted of alternating beds of silty sand and lenticular-bedding medium sand layers with shells, crustaceans, burrows, plant fragments, and pumice at depths from 12.85 to $14.20 \mathrm{~m}$. The lower unit included sandy silt layers with plant fragments, crustaceans, and bioturbation at depths from 14.20 to $15.55 \mathrm{~m}$. Intertidal species of mollusks, such as Cerithium coralium Kiener, 1841 and Estellarca olivacea (Reeve, 1844), which live in environments from subtidal to intertidal, were found in this facies. No ostracoda or foraminifera were identified. The sand content and bulk density were 0.8 to $13 \%$ and 1.10 to $1.46 \mathrm{~g} / \mathrm{cm}^{3}$, respectively, at depths from 13.28 to $15.53 \mathrm{~m}$. The $\delta^{13} \mathrm{C}$ values of bioclasts were distributed from -4.7 to $-19.3 \%$. The ${ }^{14} \mathrm{C}$ ages of leaves, Brachyura, and intertidal bivalves from depths of 12.96 to $15.415 \mathrm{~m}$ were measured to be 7170 to $7850 \mathrm{BP}$.

\section{Interpretation}

The coexistence of terrestrial plant remains and intertidal mollusks indicates that this sediment was formed in an environment with a mixture of freshwater from a terrestrial source and saline water from a marine source, such as a tidal flat or an estuary. The decrease in the number of crustaceans and the amount of bioturbation with decreasing 
depth indicates an upward-deeping environments associated with a change in sea level and/or the transportation of sediments. The increase in the $\delta^{13} \mathrm{C}$ value with decreasing depth clearly supports this interpretation. The absence of rootlets in this sediment implies that it was not deposited in an area shallower than an intertidal zone.

\section{Inner Bay Facies (core depth of 9.70-12.85 m)}

\section{Description}

This sediment consisted of fine soft mud and sandy silt beds with a few sand layers, marine shells, bioturbation, burrows, terrestrial plant fragments, Euechinoidea, and crustaceans. This sediment was also devided into two units. The upper unit contained a sandy silt bed with parallel-laminated medium sand layers with shells, crustaceans, burrows, plant fragments, and concretions at depths from 9.70 to $11.40 \mathrm{~m}$. The lower unit contained a fine soft mud bed with shells, burrows, and bioturbation at depths from 11.40 to $12.85 \mathrm{~m}$. Subtidal species of mollusks, such as Macoma tokyoensis Makiyama, 1927, E. olivacea living in subtidal and intertidal environments, and $C$. coralium living in intertidal environments were found in this facies. Benthic foraminifera, such as Ammonia beccarii (Linnaeus, 1758) were recognized at depths from 11.70 to $12.81 \mathrm{~m}$; however, no ostracoda were found in this facies. The sand content and bulk density were 0.7 to $21 \%$ and 0.96 to $1.50 \mathrm{~g} / \mathrm{cm}^{3}$, respectively, at depths ranging from $10.26 \mathrm{~m}$ to $12.79 \mathrm{~m}$. The $\delta^{13} \mathrm{C}$ values of the bioclast were 2.6 to $-8.4 \%$. The ${ }^{14} \mathrm{C}$ ages of plant fragments, leaves, and subtidal to intertidal mollusks samples from depths of 10.62 to $12.41 \mathrm{~m}$ were from 6480 to $7590 \mathrm{BP}$.

\section{Interpretation}

The fine mud with subtidal shells and foraminifera as well as a few terrestrial plant remains suggests that this sediment was deposited in a deeper water environment, such as an inner bay. The decrease in the number of crustaceans and the amount of bioturbation with decreasing depth indicates an upward-deeping environment associated with a change in sea level and/or the transportation of sediments. The increase in the $\delta^{13} \mathrm{C}$ values of shells clearly supports this interpretation because $\delta^{13} \mathrm{C}$ level is generally higher in marine water than fresh water. Deeper marine environment has less chance to be affected by fresh water.

\section{Kikai-Akahoya Volcanic Ash Facies (core depth of 8.15-9.70 m)}

\section{Description}

This facies could be divided into an upper unit having sandy mud with volcanic ash at depths from 8.15 to $9.00 \mathrm{~m}$ and a lower unit containing alternating beds of sand and mud at depths from 9.35 to $9.70 \mathrm{~m}$. Unfortunately, the boundary between these units corresponded to the boundary of the sediment cores. The layer of basal sand/mud alternating beds was $35 \mathrm{~cm}$ thick, and had mud clasts, terrestrial plant fragments, planar lamination, and no marine carbonate samples. The sand layers mainly consisted of fine to medium sand. A tephra horizon was identified by a high concentration of volcanic glass with bubble walls, small amounts of brown glass, and pumice fragments at a depth of $9.55 \mathrm{~m}$. This was correlated with the widespread K-Ah tephra (Machida and Arai 2003). The upper unit of sandy mud consisted of parallel-laminated abundant volcanic glass, pumice grains $2-3 \mathrm{~mm}$ in diameter, plant fragments, and the uppermost rootlets. The sand content and bulk density were $16 \%$ and $1.40 \mathrm{~g} / \mathrm{cm}^{3}$, respectively, at the depth of 9.67 to $9.70 \mathrm{~m}$. The ${ }^{14} \mathrm{C}$ age of a twig from the depth of $9.565 \mathrm{~m}$ was $6100 \pm 40 \mathrm{BP}$. 


\section{Interpretation}

The sand bed at the base of the K-Ah was identified as a tsunami deposit generated by the K-Ah eruption (Maeno et al. 2006; Maeno and Imamura 2007). This tsunami deposit was also reported at the Oita area (Fujiwara et al. 2010; Nakanishi et al. 2017c), north of the drilling site, at the Sukumo area (Tsuji et al. 2018; Nakanishi et al. 2019), northeast of the drilling site (Figure 1B). The parallel-laminated sandy mud implies that it was formed in an intertidal environment. The uppermost rootlets in this sediment suggest that it had been changed to an area shallower than the intertidal zone.

\section{Delta Plain Facies (core depth of 7.60-8.15 m)}

\section{Description}

This sediment consisted of parallel-laminated mud with abundant terrestrial plants. The concentration of plant fragments was higher toward the upper portion. The sand content and bulk density were 38 to $88 \%$ and 0.33 to $1.18 \mathrm{~g} / \mathrm{cm}^{3}$, respectively, at the depth of 7.69 to $8.135 \mathrm{~m}$.

\section{Interpretation}

The fine parallel-laminated mud with abundant terrestrial plant remains suggests that this sediment was deposited in a freshwater environment around a coast, such as a delta plain. The increase in the sand content and the decrease in bulk density with decreasing depth reflect the increase of plant remains associated with a change in sea level and/or the transportation of sediments.

\section{Artificial Soil Facies (core depth of $6.60-7.60 \mathrm{~m}$ )}

\section{Description}

This sediment could be divided into an upper unit with alternating beds of sandy mud from the depth of 6.60 to $6.70 \mathrm{~m}$ and muddy sand and a lower unit including an organic mud bed with abundant plant remains, such as leaves, wood fragments, and rootlets at depths from 6.70 to $7.60 \mathrm{~m}$. The upper unit had a deformation structure. Gravel layers were found around depths of 7.00 and $7.50 \mathrm{~m}$. The sand content and bulk density were $87 \%$ and $0.22 \mathrm{~g} / \mathrm{cm}^{3}$, respectively, at depths of 6.96 to $7.00 \mathrm{~m}$. The ${ }^{14} \mathrm{C}$ age of leaves from the depth of $6.955 \mathrm{~m}$ was $3050 \pm 40 \mathrm{BP}$.

\section{Interpretation}

The upper unit was artificial filler for the construction of a playground according to the land use history. The lower unit could be a paddy field since a similar organic mud bed was interpreted in this way for an archaeological excavation around the drilling site (Miyazaki City Board of Education 2010). Therefore, we concluded that this sediment was formed by human activity.

\section{DISCUSSION}

\section{Accumulation Curves}

Two accumulation curves were constructed according to $20{ }^{14} \mathrm{C}$ ages of plant remains and shells from the MIK core, which were interpreted according to the scattering pattern in an age/depth diagram and by stratigraphic study (Figure 3). The terrestrial accumulation curve was 
consistent with the eruption age of K-Ah, 7165-7303 cal BP (Smith et al. 2013), and the tephra horizon. The age/depth diagram clearly indicated that no samples used in this study were reworked.

\section{Tectonic Uplift}

The K-Ah tephra and tsunami deposit was identified at the elevation of $+4.38 \mathrm{~m}$. This is significantly higher than on the Oita Plain with an elevation of $-36 \mathrm{~m}, 147 \mathrm{~km}$ north of the drilling site of the MIK core (Nakanishi et al. 2017c), and the Sukumo Plain with an elevation of $-19 \mathrm{~m}, 167 \mathrm{~km}$ northeast of the MIK coring site (Nakanishi et al. 2019). These horizons were identified at the uppermost part of the transgressive inner bay or prodelta sediments, and then they had been covered by deltaic inner bay or deltaic sediments. The change in sedimentary system would be associated with not only the glaciohydroisostatic sea-level rise during the Holocene (Yokoyama et al. 1996), but also a huge amount (ca. $100 \mathrm{~km}^{3}$ ) of K-Ah volcanic ash (Machida and Arai 2003) and local tectonic movement due to the convergence of the Philippine Sea Plate (Fitch and Scholz 1971). The uplifted K-Ah tephra and tsunami deposit in the Miyazaki Plain was consistent with the geomorphological interpretation of marine terraces and modern geophysical observation (Nagaoka 1986; Nagaoka et al. 1991; Hasegawa et al. 2018).

\section{Marine Reservoir Effects}

Eight offsets in ${ }^{14} \mathrm{C}$ ages between plant remains and bioclast pairs from the same horizons of the MIK core were interpreted to evaluate the marine reservoir effect for 7300 to $8200 \mathrm{cal}$ BP (Figure 3). The calculated reservoir ages (R) ranged from $440 \pm 60$ to $610 \pm 60$ years, and the total average and standard deviation value was $530 \pm 50$ years for this time span. The average values from the tidal flat and inner bay sediments were $520 \pm 30(\mathrm{n}=5)$ and $540 \pm 80 \quad(n=4)$ years, respectively. In contrast, the average $\delta^{13} \mathrm{C}$ values of the bioclasts from the tidal flat and inner bay sediments were $-12.3 \pm 5.7$ and $-3.6 \pm 4.8 \%$, respectively. The relationship indicates that the $\mathrm{R}$ ages were almost constant although their $\delta^{13} \mathrm{C}$ values were clearly different at the Miyazaki Plain. Similarly, high R values were also reported on the isolated lagoon from marine inputs at the Palavasian lagoon complex on the south coast of France (Sabatier et al. 2010) and on the east coast of Korea (Nakanishi et al. 2017b).

The results for the MIK core were approximately 0 to 200 years larger than the previous values obtained from Hakata Bay, the Oita plain, the Sukumo Plain, and the South China Sea for 7000 to 9000 cal BP (Figure 4, Nakanishi et al. 2017a, 2017c, 2019; Yu et al. 2010). However, the values were approximately 0 to 400 years larger than that those obtained from the Korean Peninsula and off of Taiwan for 7000 to 9000 cal BP (Figure 4, Nakanishi et al. 2013, 2015, 2017b; Yang et al. 2018). A significantly large difference (ca. 600 years) in $\mathrm{R}$ value was recognized between the Miyazaki Plain and the southwestern coast of the Korean Peninsula for 7800 to $8200 \mathrm{cal}$ BP (Figure 4). This timing corresponds to the $8.2 \mathrm{ka}$ cooling event (Alley et al. 1997; Park et al. 2018) and the early Holocene sea-level rise (Hori and Saito 2007). These sudden paleoenvironmental changes might have caused regional fluctuations in the marine reservoir effect. 


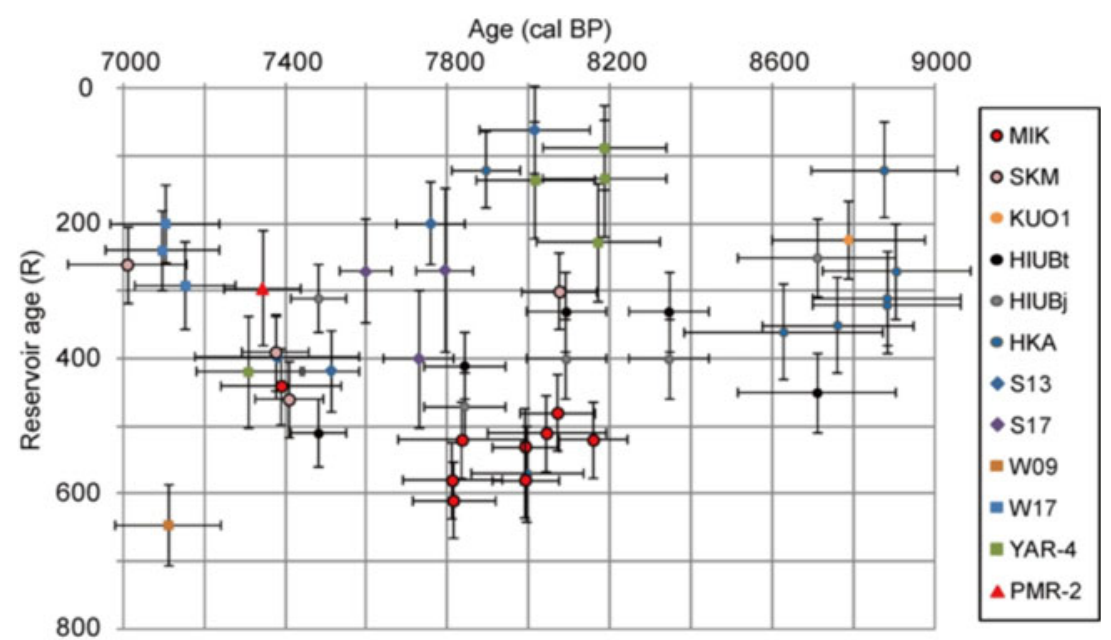

Figure 4 Reservoir ages of the MIK core and cores in previous studies. SKM was from the Sukumo Plain (Nakanishi et al. 2019). KUO1 was from the Oita Plain (Nakanishi et al. 2017c). HKA and HIUB were from Hakata Bay (Nakanishi et al. 2017a). S13, S17, W09 and W17 were from the south and west coasts of Korea (Nakanishi et al. 2015). YAR-4 was from the southwest coast of Korea (Nakanishi et al. 2013). PMR-2 was from the east coast of Korea (Nakanishi et al. 2017b).

\section{CONCLUSIONS}

Four sedimentary facies were identified, namely, tidal flat, inner bay, K-Ah volcanic ash, and delta plain beneath the Miyazaki Plain off the southeastern coast of Kyushu Island. Reservoir ages were determined from nine marine bioclast and terrestrial plant pairs in the sediments of the transgressive tidal flat and inner bay facies, and the average value for 7300 to $8200 \mathrm{cal} \mathrm{BP}$ was $530 \pm 60$ years, ranging from $370 \pm 70$ to $610 \pm 70{ }^{14} \mathrm{C}$ years. This value is approximately 0 to 200 years larger than values obtained from Hakata Bay, the Oita Plain and the Korean Peninsula for 7000 to $9000 \mathrm{cal} \mathrm{BP}$, and 0 to 400 years larger than the values obtained off of Taiwan and the South China Sea for 7000 to 9000 cal BP.

\section{ACKNOWLEDGMENTS}

This manuscript was improved by costructive comments from Prof. Alessandro Amorosi and an anonymous referee. This core was obtained by the Grants-in-Aid for Scientific Research (Kakenhi 16K03159) funded by the Japan Society for the Promotion of Science (JSPS). This study was also partially funded by the JSPS Kakenhi grant number 18H01310 and supported by the Basic Research Project of the Korean Institute of Geoscience and Mineral Resouces (KIGAM) funded by the Ministry of Science and ICT of Korea.

\section{REFERENCES}

Alley RB, Mayewski PA, Sowers T, Stuiver M, Taylor KC, Clark PU. 1997. Holocene climatic instabillity: A prominent, widespread event 8200 yr ago. Geology 25:483-486.

Fitch TJ, Scholz CH. 1971. Mechanism of underthrusting in southwest Japan: a model of convergent plate interactions. Journal of Geophysical Research 76(29): 7260-7292.
Fujiwara O, Machida H, Shiochi J. 2010. Tsunami deposit from the 7300 cal BP Akahoya eruption preserved in the Yokoo midden, north Kyushu, West Japan. The Quaternary Research (Daiyonki Kenkyu) 49(1): 23-33. In Japanese with English abstract.

Hasegawa S, Shimoyama S, Takemura K. 2018. Neotectonics during Late Quaternary in Miyazaki 
Plain deduced from height of ancient shorelines. Chikyu monthly/special (Gougai Chikyu) no.69: 55-63. In Japanese.

Hong W, Park JH, Kim KJ, Woo HJ, Kim JK, Choi HK, Kim GD. 2010a. Establishment of chemical preparation methods and development of an automated reduction system for AMS sample preparation at KIGAM. Radiocarbon 52(3):1277-1287.

Hong W, Park JH, Sung KS, Woo HJ, Kim JK, Choi HW, Kim GD. 2010b. A new1MV AMS facility at KIGAM. Radiocarbon 52(2):243-251.

Hori K, Saito Y. 2007. An early Holocene sea-level jump and delta initiation. Geophysical Research Letters 34: L18401. doi: 10.1029/2007GL031029.

Jull AJT, Burr GS, Hodgins GWL. 2013. Radiocarbon dating, reservoir effects, and calibration. Quaternary International 299: 64-71.

Kino Y, Kageyama K, Okumura K, Endo H, Fukuta O, Yokoyama S. 1984. Geology of the Miyazaki district. Quadrangle Series, scale 1: 50,000, Geological Survey of Japan. 100 p. In Japanese with English abstract.

Koike K, Machida H. 2001. Atlas of Quaternary marine terraces in the Japanese Islands. University of Tokyo Press. 105 p.

Machida H, Arai F. 2003. Atlas of tephra in and around Japan. University of Tokyo Press. $336 \mathrm{p}$.

Maeno F, Imamura F, Taniguchi H. 2006. Numerical simulation of tsunamis generated by caldera collapse during the $7.3 \mathrm{ka}$ Kikai eruption, Kyushu, Japan. Earth Planets Space 58:1-12.

Maeno F, Imamura F. 2007. Numerical investigations of tsunamis generated by pyroclastic flows from the Kikai caldera, Japan. Geophysical Research Letters 34: L23303. doi: 10.1029/2007GL031222.

Miyazaki City Board of Education. 2010. Ikime ancient tombs (Ikime Kofun gun). Miyazaki City Cultural Property Survey Report (Miyazaki-shi Bunkazai Chosa Houkokusyo) no. 80: 74 p. In Japanese.

Nagaoka S, Maemoku H, Matsushima Y. 1991. Evolution of Holocene costal landforms in the Miyazaki plain, southern Japan. The Quaternary Research (Daiyonki Kenkyu) 30(2): 59-78. In Japanese with English abstract.

Nagaoka S. 1986. The landform evolution of late Pleistocene in the Miyazaki Plain, south Kyushu, Japan. The Quaternary Research (Daiyonki Kenkyu) 25:139-163. In Japanese with English abstract.

Nakanishi T, Hong W, Shimoyama S, Sato S, Park G, Lee JG. 2017a. Radiocarbon age offset between shell and plant pairs in the Holocene sediments under the Hakata Bay, western Japan. Radiocarbon 59(2):423-434.

Nakanishi T, Hong W, Sung KS, Lim J. 2013. Radiocarbon reservoir effect from shell and plant pair in Holocene sediments around the Yeongsan
River in Korea. Nuclear Instruments and Methods in Physics Research B 294:444 451.

Nakanishi T, Hong W, Sung KS, Nakashima R, Nahm WH, Lim J, Katsuki K. 2017b. Offset in radiocarbon age between plant and shell pairs in Holocene sediment around the Mae-ho Lagoon on the eastern coast of Korea. Quaternary International 447:3-12.

Nakanishi T, Hong W, Sung KS, Sung KH, Nakashima R. 2015. Offsets in radiocarbon ages between plants and shells from same horizons of coastal sediments in Korea. Nuclear Instruments and Methods in Physics Research B 361:670-679.

Nakanishi T, Takemura K, Matsuyama H, Shimoyama S, Hong W, Okuno M. 2017c. Activity of the Funai fault and radiocarbon age offsets of shell and plant pairs from the latest Pleistocene to Holocene sediments beneath the Oita Plain, western Japan. Radiocarbon 59(6):1737-1748.

Nakanishi T, Tsuji T, Nanayama F, Yamaguchi T, Kondo Y, Ikeda M, Hong W. 2019. Radiocarbon age offsets of plant and shell in the Holocene sediments from the Sukumo Plain, southwest coast of Shikoku, Japan. Radiocarbon 61(6). This issue.

Okutani T. 2000. Marine mollusks in Japan. Tokai University Press. 1173 p. In Japanese with English abstract.

Park J, Hong W, Woo HJ, Choi HW, Kim J, Kim GD. 2010. Simple pretreatment method development for iron calcium carbonate samples. Radiocarbon 52(2-3):1295-300.

Park J, Park J, Yi S, Kim JC, Lee E, Jin Q. 2018. The $8.2 \mathrm{ka}$ cooling event in coastal East Asia: High-resolution pollen evidence from southwestern Korea. Scientific Reports 2018(8):12423. doi: 0.1038/s41598-018-31002-7.

Reimer PJ, Bard E, Bayliss A, Beck JW, Blackwell PG, Bronk Ramsey C, Buck CE, Cheng H, Edwards RL, Friedrich M, Grootes PM, Guilderson TP, Haflidason H, Hajdas I, Hatté C, Heaton TJ, Hoffmann DL, Hogg AG, Hughen KA, Kaiser KF, Kromer B, Manning SW, Niu M, Reimer RW, Richards DA, Scott EM, Southon JR, Staff RA, Turney CSM, van der Plicht J. 2013. IntCal13 and Marine13 radiocarbon age calibration curves $0-50,000$ years cal BP. Radiocarbon 55(4):1869-1887.

Sabatier P, Dezileau L, Blanchemanche P, Siani G, Condominines M, Bentaleb I, Piques G. 2010. Holocene variations of radiocarbon reservoir ages in a Mediterranean lagoonal system. Radiocarbon 52(1):91-102.

Smith VC, Staff RA, Blockley SPE, Bronk Ramsey C, Nakagawa T, Mark DF, Takemura K, Danhara T, Suigetsu 2006 Project Members. 2013. Identification and correlation of visible tephras in the Lake Suigetsu SG06 sedimentary archive, Japan: chronostratigraphic markers for synchronizing of east Asian/west Pacific 
palaeoclimatic records across the last $150 \mathrm{ka}$. Quaternary Science Review 67:121-137.

Stuiver M, Pearson GW, Braziunas T. 1986. Radiocarbon age calibration of marine samples back to 9000 cal yr BP. Radiocarbon 28(2B):980-1021.

Stuiver M, Reimer PJ, Reimer RW. 2018. CALIB 7.1 [WWW program] at http://calib.org, accessed 2018-2-24.

Tsuji T, Nanayama F, Yamaguchi T, Ikeda M, Nakanishi T, Kondo Y, Maeno F, Hongo C, Kumura K. 2018. Outline of the Sukumo core and event deposit related with Kikai Akahoya volcanic ash, southwest coast of Shikoku, Japan. Abstract of Japan Geoscience Union Meeting, MIS11-P19.
Yang RJ, Wang SL, Burr GS, Liu JT, Fan D. 2018. Holocene variation of radiocarbon reservoir age offshore western Taiwan, derived from paired charcoals and mollusks. Quaternary International. doi: 10.1016/j.quaint.2018.07.001.

Yokoyama Y, Nakada M, Maeda Y, Nagaoka S, Okuno J, Matsumoto E, Sato H, Matsushima Y. 1996. Holocene sea-level change and hydroisostacy along the west coast of Kyushu, Japan. Paleogeography, Paleoclimatology, Paleoecology 123(1-4): 29-47.

Yu K, Hua Q, Zhao JX, Hodge E, Fink D, Barbetti M. 2010. Holocene marine ${ }^{14} \mathrm{C}$ reservoir age variability: evidence from ${ }^{230} \mathrm{Th}$-dated corals in the South China Sea. Plaeoceanography 25: PA3205. 